\title{
Ownership and management changes on California hardwood rangelands: 1985 to 1992
}

\author{
LYNN HUNTSINGER, LITA BUTTOLPH, AND PETER HOPKINSON
}

\begin{abstract}
Authors are associate professor, Department of Environmental and Resource Sciences MS 186, University of Nevada, Reno, Nev. 89512; graduate student researcher, Department of Rangeland Resources, Utah State University, Logan, Ut,; and graduate student researcher, Environmental Science, Policy, and Management, University of California, Berkeley, Calif.
\end{abstract}

\author{
Abstract
}

Results of a 1985 survey of California hardwood rangeland landowners were used to develop a multi-agency research and extension program known as the Integrated Hardwood Range Management Program. In 1992, the same properties were re-surveyed. Although the results cannot prove the program is the sole or direct agent of change, program-sponsored education and research aimed at encouraging oak rangeland owners to change oak management practices is reflected in changes in key landowner behaviors. Program-sponsored research showed that intermediate levels of oak canopy cover did not significantly reduce forage production. Concurrently, landowners have significantly reduced the clearing of oaks for forage production. Other significant changes are reduction of cutting of living oaks for any reason, reduced cutting of oaks for fuelwood, increased use of oak promoting practices, and a growing awareness of the need to be concerned about the status of oaks. Landowners who were aware of the resource benefits of having oaks, or who believed oaks were threatened, or who had been in contact with a natural resource advisory service were significantly more likely to carry out oak-promoting practices. Between 1985 and 1992, many properties changed hands: $24 \%$ of parcels were sold but remained intact, while an additional $11 \%$ were subdivided. As was found in 1985, owners of smaller properties manage for different and more diverse goals than those of larger properties. The changing pattern of hardwood rangeland land ownership will have an impact on education and conservation programs.

Key Words: oak woodlands, Quercus, landowners, land use, management, values

A 1985 statewide survey of the goals, characteristics, and management practices of California hardwood rangeland landowners was instrumental in developing the research and extension components of the multi-agency "Integrated Hardwood Range Management Program" (IHRMP) (Huntsinger and Fortmann 1990). As coordinated among the University of California Cooperative Extension, the California Department of Forestry and Fire Protection, and other agencies, program goals included reducing the loss of oaks in the state, researching ways to encour-

\footnotetext{
The authors wish to thank Paul F. Starrs and Wifredo de Rafols for the Spanish abstract, Robin Liffmann, John Tanaka, and the anonymous reviewers for their helpful comments. Louise P. Fortmann headed the development of the 1985 survey.

Manuscript accepted 21 Sep. 1996.
}

Resúmen

Una encuesta, hecha en 1985, de las opiniones de aquellos terratenientes californianos cuyas tierras producen maderas nobles, dio resultados que fueron utilizados para desarrollar un programa de extensión e investigación, compuesto de varias agencias gubernamentales, conocido por el nombre de "Integrated Hardwood Range Management Program." Las mismas tierras fueron sondeadas en 1992. Aunque no se puede comprobar que la indole de los nuevos datos tenga una relación directa o de causa y efecto con dicho programa, parece ser que la educación y las investigaciones llevadas a cabo (para fomentar que los propietarios de robledos cambiaran sus modos de administración) se ven reflejadas en el comportamiento de ciertos propietarios claves. Investigaciones patrocinadas por el programa indican que niveles medios de población arbórea y, por consecuencia, de sombra no reducen significativamente la producción de forraje. $A$ la vez, los propietarios han aminorado notablemente la práctica de despoblar robles para producir forraje. Otros cambios importantes han sido la reducción del corte de robles vivosbien sea para leña o para cualquier propósito-, el aumento de prácticas que ascienden la supervivencia del roble, y mayor conciencia del valor del mismo. Los propietarios que eran conscientes de los beneficios del cultivo del roble, los que creían que el roble se encontraba en peligro, o los que habían estado en contacto con un servicio de asesoramiento de recursos naturales, estaban notablemente más dispuestos a llevar a cabo prácticas que benefician el roble. Muchas propiedades cambiaron de manos entre los años 1985 y 1992: el $24 \%$ se vendieron y quedaron intactas, mientras que el 11\% fueron parceladas. Igual que en 1985, los propietarios de terrenos pequeños exhiben modos de administración encauzados por objetivos distintos y más diversos que los de propietarios de terrenos grandes. La cambiante parcelación de terrenos con maderas nobles tendrá un impacto sobre programas dedicados a la educación y conservación de recursos naturales.

age appropriate management of the woodlands by landowners, and researching the causes of oak regeneration failure. The vast majority of California's hardwood rangelands are privately owned, providing about a third of the state's total rangeland livestock forage. In order to develop effective research programs and education materials, it was necessary to discern who the owners of hardwood rangelands were, what their goals were, and to what incentives they would be most receptive. In 1992, the current owners of the same random selection of properties from 1985 
were re-surveyed, regardless of changes in ownership or land use. Because selected properties were surveyed at 2 different times, results offer opportunity to answer at least 2 kinds of questions central to the conservation of hardwood rangelands: What is the rate and nature of rangeland land use change? Since program implementation, have landowner practices and values changed? This paper compares results of the second survey to those of the first and addresses these questions for the years from 1985 to 1992.

A variety of surveys have been conducted in California's hardwood rangelands in recent years (McClaran and Bartolome 1985, Stewart 1991, Johnson 1996, Richards and George 1996), but none has been based on a randomly selected, statewide sample of hardwood rangeland ownerships. Nevertheless, they generally support the results of the 1985 survey showing that the majority of landowners value at least some oaks on their property for a variety of reasons and are often actively managing them. Fieldbased inventory and monitoring projects examining land use and oak management practices also supported the results of the 1985 survey (Bolsinger 1988, Ewing et al. 1988, Holzman 1993, Swiecki and Bernhardt 1993), finding, for example, that about three-quarters of hardwood rangelands are grazed by livestock and that conversion and fragmentation are serious problems. However, field inventories only indirectly and inferentially reveal landowner goals, practices, and values.

The 1985 survey identified groups of landowners with quite different interests and characteristics, indicated that ownership of the woodlands was fairly fluid, and showed fragmenting of parcels by subdivision to be a growing problem in the woodlands (Fortmann and Huntsinger 1989, Huntsinger and Fortmann 1990). Two archetypal hardwood rangeland landowner classes were described, each owning at least a third of the woodlands (Table 1). These archetypes were used to develop education packages targeted to landowners statewide. This re-survey allows examination of trends in land ownership, land uses, and management practices since 1985 , and offers insight into the effectiveness of the IHRMP. The objectives of the 1992 survey were to:

1. contribute to the further development of the Integrated Hardwood Range Management Program's (IHRMP) education and research activities, and provide information for legislators;

2. examine demographic characteristics, attitudes, management practices, and land uses of hardwood rangeland landowners in 1992;

3. examine changes between 1985 and 1992, including change in land ownership and landowner behavior; and,

4. do a preliminary exploration of water quality-related landowner practices and land uses, because water quality policy and regulation is an important issue for California rangeland landowners.

\section{Study Area}

The 3 million ha of California hardwood rangeland (also referred to as oak woodland or foothill woodland) (Ewing et al. 1988 ) intermix with valley annual grasslands at low elevations, and with montane forest at upper elevations. Characterized by an oak (Quercus spp.) overstory and annual grass (Bromus spp.,
Table 1. The hardwood rangeland archetypes identified as characterizing respondents in the 1985 and 1992 surveys.

\begin{tabular}{cc}
\hline Owner of Small Property & Owner of Large Property \\
\hline doesn't sell products from land & sells products, most often livestock \\
more often absentee & resident owner \\
more recent arrival & long term owner \\
relatively amenable to oak use regulation & anti-regulation \\
less than half cut living oaks & most cut living oaks \\
growing in numbers & relatively stable in number \\
\hline
\end{tabular}

Avena spp., Hordeum spp., Festuca spp., Vulpia spp., Medicago spp., Trifolium spp.) understory, they occupy coastal and valley foothills throughout most of the state in the Mediterranean climate zone (James 1966) from sea level to about $2,000 \mathrm{~m}$ elevation. Canopy cover varies from complete closure in the dense thickets found in canyons to open savanna woodlands characteristic of foothill slopes. The type and its many variations are described thoroughly by Griffin (1978). More than $80 \%$ of the woodlands are in private ownership (Ewing et al. 1988).

Hardwood rangelands can be thought of as an ecosystem at risk. Much of the value and character of this woodland has to do with its being large and contiguous. Unsuited to crop or forest production, the foothill woodlands remain a vast, often interconnected acreage running through 38 of California's 52 counties home to more wildlife than any other major habitat type in the state (Mayer et al. 1986). Migratory and resident mule deer, mountain lions, raptors, and a host of species can maintain viable populations in the unfragmented, acorn-producing woodlands. Stock grazing has been the dominant use of these lands since the European settlement of California (Burcham 1982), and mid-elevation woodlands often are a key component of California's traditional transhumant grazing practices.

There are 2 major forces that most threaten the extensive hardwood rangeland. In the early decades of the century millions of hectares of hardwood rangeland in valley bottoms were converted to cropland. Today, conversion for residential use is gobbling up woodland (Bolsinger 1988). Planners, confronted with a choice of steering development to prime farmland or forest, often settle on the woodlands as marginal in economic value and attractive to prospective residents. Land values in many woodland areas are far higher than those justifiable by range livestock production (Hargrave 1993, Johnson 1996). Property tax reduction incentive programs like the California Land Conservation Act (CLCA or Williamson Act) have been shown to be effective when firm land use zoning designations support them, but these are often lacking (McClaran et al. 1985).

The second major risk to hardwood rangelands is a perceived lack of recruitment of oaks in the woodlands (Muick and Bartolome 1987). Scientists and lay people alike have noted an absence of mid-sized oak trees in many areas. Seedlings can be found, older trees are obvious, but mid-sized or sapling-sized trees may be surprisingly sparse or absent. Concerns that some parts of the woodland will eventually disappear due to attrition are exacerbated by the harvest of oaks for fuel and for increasing forage production. In 1985, when the Integrated Hardwood Range Management Program (IHRMP) was conceived, it was believed that this kind of oak removal was a serious problem in the woodlands. 


\section{Methods}

In spring of 1985 and 1992, after pre-testing with selected landowners not part of the study sample, private owners of hardwood rangeland throughout the state were surveyed by mail, using the standard four-wave technique described by Dillman (1978) to achieve a high response rate. The greater the response rate, the less "self-selection" influences responses and hence the greater the representativeness of the sample.

Questionnaires were sent to the owners of land containing the Forest Inventory Assessment plots previously used to assess hardwood volume in California (Bolsinger 1988). The plots were established at the intersection points of a randomly established eleven-square-kilometer grid overlaid on the state. Plots designated as "Hardwood Woodland Type," (USDA, Forest Service 1981) were selected for this study if an overstory of $10 \%$ or greater canopy cover was predominately Quercus spp. and the plot was on private land. By definition, these lands do not show evidence of ever having had $10 \%$ or more cover of trees of industrial roundwood species and quality. Usable plots occurred in 38 of the state's 58 counties, at elevations ranging from 80 to $1,800 \mathrm{~m}$.

Usable questionnaires were returned by 126 of 166 eligible respondents for a response rate of $76 \%$ in 1985 and 121 of 151 eligible respondents for a response rate of $80 \%$ in 1992 . Of the properties successfully surveyed in $1985,87 \%$ were successfully re-surveyed in 1992. More than $10 \%$ of California's total hardwood rangelands were owned by the respondents to each survey. In 1992, every effort was made to locate and survey moved or new owners of properties in the sample. This involved travel to the county assessor's office and an examination of plat maps and title transfers. The 1992 respondents include those who purchased, inherited, or took over management of a family property since 1985 , some who did not respond to the 1985 survey, as well as those maintaining ownership of the property since 1985. As a result, only about $30 \%$ of the respondents in 1992 reported that they participated directly in the 1985 survey. For all survey questions, no significant differences were found in the responses of the $30 \%$ who participated in the 1985 study and those of new respondents.

The grid method used to establish Forest Inventory Plots means that larger properties have a greater probability of being selected for the sample (Wensel 1983). While this resulted in a sample with good representation of landowners of each property size, it means that responses about land use practices cannot be directly extrapolated to the hardwood rangeland as a whole. For this reason, responses to each question were evaluated in 2 ways. First, contingency table analysis was used to make comparisons of the mean responses and responses by 3 property size categories of landowners between 1985 and 1992 . The 3 property size categories were those used in the 1985 study (under 80 ha, 80 to $2,008 \mathrm{ha}$, and greater than 2,008 ha). Changes by property size category are mentioned when they are of interpretive value and significant at $P<0.1$. The Chi-square statistic was used to determine significance for categorical variables, while a t-test was used to compare grouped continuous variables (Spicer 1972).

Second, in order to estimate the amount of hardwood rangeland potentially affected by certain landowner management practices or demographic characteristics, responses were weighted in inverse proportion to size of ownership relative to Forest Inventory Plot grid size (weight=grid size/property size) up to the size of the grid as described in Wensel (1983). This adjusts the distribution of ownership sizes in the sample to make it comparable to that of ownerships in the hardwood rangeland as a whole, so estimates of the proportion of total hardwood rangeland owned by landowners who claim certain practices and particular demographic characteristics can be developed (Wensel 1983). Analyses using the weighted sample are identified in the tables.

Landowners were asked about their demographic characteristics, attitudes, land tenure, land use, and management practices. Questions are condensed in the tables presenting results.

\section{Results}

Overall, landowners still fall into the archetypes described as a result of the 1985 study (Huntsinger and Fortmann 1990) (Table 1). The relationships between property size and landowner goals, attitudes, and practices remain consistent with those of the results of the 1985 survey (Huntsinger and Fortmann 1990). However, since 1985 there have been changes in land status, owner characteristics, management, and attitudes about oaks.

\section{Sample Histories and Characteristics}

In the 7 years between 1985 and 1992, about $1 \%$ of the owners of parcels in the original sample moved and could not be re-located for survey purposes. One parcel was donated to a public park agency. A little less than two-thirds of the parcels, $63 \%$, remained

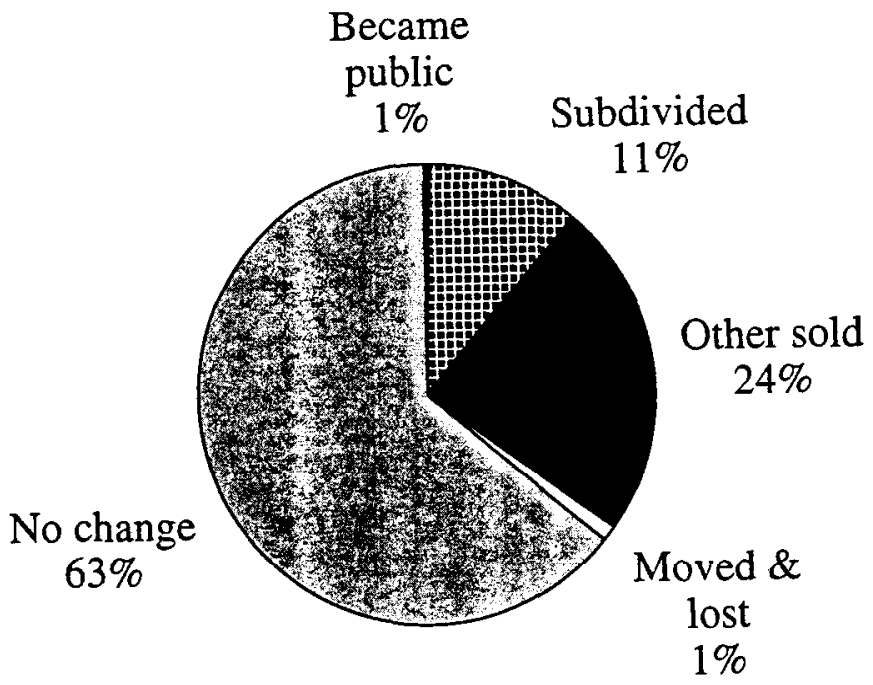

Fig. 1. Land ownership change in the original sample, 1985 to 1992 ( $\mathrm{n}=194)$.

in the same ownership (Fig. 1). During the same period, $24 \%$ of the parcels in the original sample were sold but remained intact. An additional $11 \%$ were subdivided into smaller parcels, with about half sold to new owners. Altogether an average of about $4 \%$ of hardwood rangeland parcels were sold each year.

The characteristics of the 1992 sample, when compared to the sample in 1985, reveal a similar distribution of land ownership sizes (Table 2). The weighted sample shows almost a halving of the mean property size among the smallest category of landown- 
Table 2. Comparison of the weighted and actual sample of hardwood rangeland landowners in California: percent of owners, land, and average property size in 1985 and 1992.

\begin{tabular}{|c|c|c|c|c|c|c|}
\hline \multirow{2}{*}{$\begin{array}{c}\text { Parcel size } \\
\text { Year } \\
\mathbf{n}^{1}= \\
\end{array}$} & \multicolumn{2}{|c|}{ Under 80 ha } & \multicolumn{2}{|c|}{80 to $2.008 \mathrm{ha}$} & \multicolumn{2}{|c|}{ Over $2.008 \mathrm{ha}$} \\
\hline & $\begin{array}{c}1985 \\
36\end{array}$ & $\begin{array}{c}1992 \\
38\end{array}$ & $\begin{array}{c}1985 \\
54\end{array}$ & $\begin{array}{c}1992 \\
54\end{array}$ & $\begin{array}{c}1985 \\
25\end{array}$ & $\begin{array}{c}1992 \\
23 \\
\end{array}$ \\
\hline Percent of owners in sample & 31 & 33 & 47 & 47 & 22 & 20 \\
\hline Percent of owners, weighted sample & 98 & 99 & 2 & 1 & 0.05 & 0.03 \\
\hline Percent of land in sample & 0.3 & 0.3 & 12 & 14 & 88 & 86 \\
\hline Percent of land, weighted sample & 29 & 32 & 42 & 44 & 29 & 23 \\
\hline
\end{tabular}

in varies slightly with each questions.

ers $(P<0.01)$ (Table 2$)$, while changes in other property size categories were not significant. Overall, using the weighted sample, mean property size declined from a mean of 13 ha in 1985 to 7 ha in $1992(\mathrm{P}<0.01)$.

\section{Owner Characteristics and Rangeland Use}

There has been no significant change in landowner demographic characteristics such as residence on property, age, education, income, or length of ownership since 1985 (Table 3). Apparently

Table 3. Characteristics of hardwood rangeland landowners in 1985 and 1992.

\begin{tabular}{|c|c|c|c|c|}
\hline $\begin{array}{l}\text { Landowners with the following } \\
\text { characteristics }\end{array}$ & $\begin{array}{c}\text { \% Land- } \\
\text { owners, } \\
1985 \\
\mathrm{n}=126^{1}\end{array}$ & $\begin{array}{c}\text { \% Land- } \\
\text { owners, } \\
1992 \\
\mathrm{n}=115^{1}\end{array}$ & $\begin{array}{c}P \\
\left(\mathrm{X}^{2}\right)\end{array}$ & $\begin{array}{c}\text { Est. }^{2} \\
\% \\
\text { ha }\end{array}$ \\
\hline & $(\%)$ & $(\%)$ & & \\
\hline College graduate & 50 & 54 & ns & 58 \\
\hline Mean age & 57 & 59 & $\mathrm{~ns}^{3}$ & \\
\hline Income 75,000 and over & 37 & 37 & $\mathrm{~ns}^{4}$ & 24 \\
\hline Land in family 21 years or more & 52 & 57 & ns & 64 \\
\hline \multicolumn{5}{|l|}{ Major source of income: } \\
\hline ranching & 27 & 22 & ns & 28 \\
\hline other & 73 & 78 & ns & 72 \\
\hline Absentee owner & 25 & 26 & ns & 21 \\
\hline $\begin{array}{l}\text { Member wildlife or } \\
\text { environmental group }\end{array}$ & 25 & 30 & ns & 34 \\
\hline $\begin{array}{l}\text { Member livestock association } \\
\text { or farm bureau }\end{array}$ & 58 & 49 & ns & 39 \\
\hline $\begin{array}{l}\text { Contact with advisory service } \\
\text { about oaks, last } 2 \text { yrs. }\end{array}$ & 24 & 26 & ns & 38 \\
\hline Female & 18 & 24 & ns & 20 \\
\hline Have a manager & 21 & 16 & ns & 28 \\
\hline
\end{tabular}

n varies slightly with each question.

estimate of $\%$ oak woodland owned by landowners with the characteristic, calculated using the weighted sample.

${ }^{3} \mathrm{P}>0.1$, t-test.

4 adjusted to 1985 dollars.

the rate of ownership turnover did not change much between 1985 and 1992. Although the pattern of results here and in Table 4 suggests a general decline in ranching and agricultural pursuits among hardwood rangeland landowners, most of these were not statistically significant changes.

Since 1985, significantly fewer owners graze livestock on their land, although livestock still graze on $71 \%$ of the woodlands (Table 4). Although for the whole sample there has been no sta- tistically significant change in the proportion of landowners carrying out practices to improve wildlife, among landowners with mid-size properties improving wildlife habitat has gone from $38 \%$ of owners in 1985 to $56 \%$ in $1992(\mathrm{P}<0.1)$, and in absolute numbers more landowners in every category in 1992 reported improving wildlife habitat.

Significantly more hardwood rangeland landowners live less than $9 \mathrm{~km}$ (5 miles) from a subdivision in 1992 (Table 4), another indication of the on-going fragmentation of the woodlands. The owners of an estimated $7 \%$ of the hardwood rangelands report having subdivided part of their land within the 5 years previous to 1992 (Table 4).

Table 4. Land use of California woodland landowners, 1985-1992.

\begin{tabular}{|c|c|c|c|c|}
\hline $\begin{array}{l}\text { Percent of } \\
\text { landowners }\end{array}$ & $\begin{array}{c}\text { \% Land- } \\
\text { owners, } \\
1985 \\
\mathrm{n}=126^{1}\end{array}$ & $\begin{array}{c}\text { \% Land- } \\
\text { owners, } \\
1992 \\
n=115^{1}\end{array}$ & $\underset{\left(\mathbf{X}^{2}\right)}{\boldsymbol{P}}$ & $\begin{array}{c}\text { Est. }^{2} \\
\% \\
\text { ha }\end{array}$ \\
\hline & $(\%)$ & (\%) & & \\
\hline Sells products from land & 86 & 79 & ns & 70 \\
\hline Produces livestock & 65 & 58 & ns & 56 \\
\hline Livestock graze property & 76 & 66 & 0.07 & 71 \\
\hline Fee hunting & 10 & 9 & ns & 15 \\
\hline Land in Williamson Act & 51 & 54 & ns & 44 \\
\hline Improves wildlife habitat & 37 & 44 & ns & 52 \\
\hline Subdivided in last 5 years & 9 & 9 & ns & 7 \\
\hline Less than 5 miles to subdivision & 49 & 69 & 0.08 & 56 \\
\hline Used for hunting & 66 & 57 & ns & 62 \\
\hline Used for recreation, vacation hom & ne 16 & 23 & ns & 18 \\
\hline
\end{tabular}

$\mathrm{n}$ varies slightly with each question.

${ }^{2}$ estimate of $\%$ oak woodland owned by landowners with each use, calculated using the weighted sample.

\section{Oak Values and Cutting Practices}

In both 1985 and 1992, oaks were highly valued for wildlife habitat, shade, and natural beauty (Table 5). In 1992, oaks were valued significantly more for browse, for erosion control, and for conserving water (Table 5).

Changes in values are apparently reflected in changes in behavior. There has been a strong and significant reduction in cutting or thinning living oaks for any purpose. The number of owners engaged in the sale of firewood, whether standing or down, has also declined (Table 5).

The reasons and relative importance of reasons for cutting oaks have changed (Table 5). Cutting oaks for home firewood and removal for increased forage production significantly declined 
Table 5. Oak values and practices of California hardwood rangeland landowners, 1985 to 1992.

\begin{tabular}{|c|c|c|c|}
\hline & $\begin{array}{c}\text { Land- } \\
\text { owners, } \\
1985 \\
\mathrm{n}=126^{1}\end{array}$ & $\begin{array}{c}\text { Land- } \\
\text { owners, } \\
1992 \\
n=115^{1}\end{array}$ & $P\left(\mathrm{X}^{2}\right)$ \\
\hline & $(\%)$ & $(\%)$ & \\
\hline \multicolumn{4}{|l|}{ The respondent values oaks for. } \\
\hline Property value & 54 & 61 & ns \\
\hline Shade & 77 & 79 & ns \\
\hline Erosion control & 73 & 83 & 0.07 \\
\hline Wildlife habitat & 80 & 84 & ns \\
\hline Natural beauty & 82 & 88 & ns \\
\hline Fuelwood & 63 & 57 & ns \\
\hline More forage underneath & 29 & 37 & ns \\
\hline Browse & 51 & 67 & 0.02 \\
\hline Conserving water & 46 & 58 & 0.07 \\
\hline \multicolumn{4}{|l|}{ Landowners who: } \\
\hline Thin oaks & 35 & 26 & 0.09 \\
\hline Cut any living oaks & 70 & 50 & 0.04 \\
\hline Sell firewood & 20 & 11 & 0.06 \\
\hline \multicolumn{4}{|c|}{ Agrees an important reason to cut oaks is: } \\
\hline Removing dead or diseased oaks & 87 & 93 & ns \\
\hline Improving access & 43 & 33 & ns \\
\hline Home firewood & 48 & 30 & 0.01 \\
\hline Increasing forage production & 45 & 28 & 0.01 \\
\hline Increasing waterflow & 23 & 15 & ns \\
\hline Clearing for development & 20 & 16 & ns \\
\hline Firewood income & 14 & 11 & ns \\
\hline \multicolumn{4}{|l|}{ Oak management practices: } \\
\hline Burn scrub oaks & 12 & 11 & ns \\
\hline Seasonally graze oaks & 43 & 47 & ns \\
\hline Protect oak sprouts & 12 & 19 & 0.09 \\
\hline Thin softwoods to promote oaks & 12 & 9 & ns \\
\hline Spray, poison, girdle oaks & 7 & 2 & 0.05 \\
\hline Plant oaks & 6 & 14 & 0.03 \\
\hline Maintain oak stocking rate & 18 & 15 & ns \\
\hline Cut mistletoe out of trees & 21 & 20 & ns \\
\hline
\end{tabular}

in varies slightly with each question.

(Table 5). Landowners with larger properties have most severely reduced harvest for increased forage production, from $62 \%$ to $38 \%$ of owners $(P<0.1)$. Clearing oaks to improve access for livestock or vehicles is now the most frequent reason the owners of large properties report for cutting oaks (besides cutting dead and diseased oaks), while increasing forage production, which used to be the major reason, now trails.

The most dramatic reduction in harvest for home firewood use was among landowners in the smallest property size category, from $64 \%$ to $36 \%(\mathrm{P}<0.1)$. Among owners of small properties, cutting firewood for home use was once the most frequently reported as an important reason to cut oaks (besides removing dead and diseased oaks), while today it is improving access.

There has been no significant change in number of landowners who clear oaks for development, or who remove dead and diseased oaks, regardless of property size. Cutting oaks for firewood sales continues among a small proportion of landowners. Using the 1992 weighted sample, an estimated $49 \%$ of the woodlands were owned by those who cut any living oaks, $37 \%$ by people who thinned oaks, and $25 \%$ by those who sold firewood from their property. While in 1985, landowners with greater than $50 \%$ oak canopy cover on their land were significantly more likely to remove living oaks, in 1992 the great reduction in number of landowners who cut oaks obscured any possible statistical significance to this relationship.

\section{Promoting Oak Growth}

Perhaps more indicative of how landowner values bear upon behavior is to examine whether or not landowners actively promote the maintenance of their oak stands (Table 5). In 1992, landowners are significantly more likely to plant oaks and to protect oak re-sprouts (Table 5). Using a scale developed by summing the frequency of carrying out 4 oak-promoting management practices, we can compare the behavior of those who value oaks for certain purposes to those who do not. The 4 practices are planting oaks, protecting oak sprouts, maintaining a fixed oak stocking level, and cutting mistletoe out of trees. Landowners who value oaks for wildlife habitat, browse, soil protection, and beauty are more likely to carry out oak promoting activities $(\mathrm{P}<$ $0.001)$, as are those who value oaks for shade $(\mathrm{P}<0.1)$. Valuing oaks for fuelwood, property values, or water conservation did not show this relationship.

Also using the scale of oak-promoting practices, landowners receiving advice about oaks from University of California advisory services within the last 2 years, and in fact from any public advisory service, were significantly more likely to carry out oak promoting practices $(\mathrm{P}<0.1)$.

Finally, those who agree with the statement that "oaks are being lost in California" (Table 6) were significantly more likely to carry out practices that benefit oaks $(P<0.001)$.

\section{Attitudes About Regulation}

In both 1985 and 1992, some standard questions about regulation were included in the survey. In 1985, landowners in all property size categories were unreceptive to the idea of regulation of resource use and regulations in general. This sentiment has continued over the last 7 years, with the overwhelming majority of landowners agreeing that regulation leads to a loss of liberties and freedom (Table 6). However, a vast majority of landowners agreed in both 1985 and 1992 that protection of water quality should be a state responsibility.

Landowner perception that oaks are declining has significantly increased (Table 6). This pattern persists throughout property size categories, as in absolute numbers, more landowners in each category agreed that oaks are being lost in California in 1992. Despite

Table 6. California oak woodland landowner attitudes toward regulation, 1985-1992.

\begin{tabular}{|c|c|c|c|}
\hline Respondents agree that: & $\begin{array}{c}\text { Land- } \\
\text { owners, } \\
1985 \\
\mathrm{n}=126^{1}\end{array}$ & $\begin{array}{c}\text { Land- } \\
\text { owners, } \\
1992 \\
\mathrm{n}=115^{1}\end{array}$ & $P\left(\mathrm{X}^{2}\right)$ \\
\hline & $(\%)$ & $(\%)$ & \\
\hline $\begin{array}{l}\text { State regulation means a loss of } \\
\text { liberties and freedom }\end{array}$ & 83 & 88 & ns \\
\hline State can regulate private land resources & 22 & 25 & ns \\
\hline $\begin{array}{l}\text { State can regulate private land with } \\
\text { compensation }\end{array}$ & 46 & 53 & $\mathrm{~ns}$ \\
\hline Oaks are being lost in California & 59 & 79 & 0.01 \\
\hline Should regulate California oak use & 32 & 39 & ns \\
\hline $\begin{array}{l}\text { Protecting water quality should be } \\
\text { a state responsibility }\end{array}$ & 88 & 85 & ns \\
\hline $\begin{array}{l}\text { The state consults adequately with } \\
\text { citizens before regulating resources }\end{array}$ & 21 & 22 & ns \\
\hline
\end{tabular}


this, change in receptivity to possible regulation of oak use has not occurred (Table 6).

\section{Water Management and Riparian Grazing Practices}

Questions about water and riparian management were asked only in the 1992 survey. About two-thirds of private hardwood rangelands (estimated from the weighted sample) are in parcels with perennial sources of surface water. Less than a fifth is in parcels with only intermittent surface water sources, and about $8 \%$ of the woodland is comprised of properties with no surface water. Most livestock producers get some forage from riparian areas, but the majority reported getting less than $10 \%$ of their forage from riparian grazing lands, although whether that is in terms of days of use, or forage weight, or some other unit of measure used by the landowner is unknown. A full valuation of these forage resources is not possible without considering seasonal demand.

Owners of large properties in particular are active managers of their water resources (Table 7). More than half divert some water and stabilize streambanks. About a third channelize streams. More than two-thirds of the owners in the largest property size class report that they graze riparian areas seasonally; almost half claim to fence and manage riparian areas separately from the rest of their woodlands (Table 7).

Table 7. Water management and oak woodland landowners, 1992.

\begin{tabular}{|c|c|c|c|}
\hline $\begin{array}{l}\text { Parcel size } \\
\text { Percent of landowners who: }\end{array}$ & $\begin{array}{c}\text { Under } 80 \\
\text { ha; } \\
\mathrm{n}=38^{1}\end{array}$ & $\begin{array}{c}80 \text { to } 2008 \\
\text { ha; } \\
n=54\end{array}$ & $\begin{array}{c}\text { Over } \\
2008 \text { ha; } \\
n=23\end{array}$ \\
\hline & \multicolumn{3}{|c|}{$\ldots \ldots \ldots$ (\%) $\ldots \ldots \ldots$} \\
\hline Graze riparian areas seasonally & $16^{22}$ & $61^{b}$ & $70^{b}$ \\
\hline Fence riparian areas & $3^{a}$ & $19^{b}$ & $41^{c}$ \\
\hline Put erosion control stuctures in streams & $8^{\mathrm{a}}$ & $17^{a}$ & $17^{\mathrm{a}}$ \\
\hline Divert water & $11^{\mathrm{a}}$ & $39^{\mathrm{b}}$ & $61^{\mathrm{c}}$ \\
\hline Graze riparian areas separately & $11^{\mathrm{a}}$ & $35^{b}$ & $78^{\mathrm{c}}$ \\
\hline Stabilize streambanks & $11^{a}$ & $35^{b}$ & $60^{c}$ \\
\hline Chanelize streams & $11^{\mathrm{a}}$ & $21^{\star b}$ & $31^{b}$ \\
\hline
\end{tabular}

n varies slightly by question.

${ }^{2}$ different superscripts within rows mean significantly different at $P<0.05$.

\section{Discussion}

Since 1985, significant changes have occurred in the hardwood rangelands and in the goals and practices of those who own them.

\section{Fragmentation is occurring}

During the period between surveys, an average of almost $4 \%$ of hardwood rangeland properties were sold each year. In general, hardwood rangeland property ownerships are becoming smaller. According to database and assessor records, about $11 \%$ of ownerships in the original sample were subdivided during the 7 years between sampling periods, coinciding well with respondent reports that $9 \%$ had subdivided some part or all of their land in the 5 years previous to 1992, or about $7 \%$ of all hardwood rangelands as estimated from the weighted sample (Table 4). Eventually, the fragmentation of properties results in the conversion of some land from woodland to housing or other intensive uses. Results of various field surveys conducted in the woodlands show an exponential decline in the amount of woodland (Huntsinger and Hopkinson 1996). Holzman (1993) found that conversion rates over the last 60 years varied regionally, with more than a third of the woodlands developed in one region, and an average conversion loss of $20 \%$ among the 5 regions studied. Ranchers interviewed in a Central Sierra study tended to believe that high land values and the estate and property taxes that go with them, coupled with irregular and low investment return from ranching, are major obstacles to the long term future of ranching in areas where development pressures are high (Johnson 1996). Hargrave (1993) found that in El Dorado County, investment returns from land appreciation often exceeded that from livestock production. Landowners report that subdivisions are closer than ever to their own properties, and with subdivision, management conflicts between agricultural producers and urban refugees also become part of the scene (Huntsinger and Hopkinson 1996).

Values and practices targeted by the IHRMP were affected

Although this type of survey cannot "prove" that the program caused people to act differently, changes in values and behavior reflect program goals. Considerable Integrated Hardwood Range Management Program (IHRMP) research was targeted to finding out how wildlife management could offer incentives to landowners to keep oaks through the marketing of hunting opportunities and habitat management, and in 1992, significantly more landowners were aware of the value of oaks as wildlife browse and more of those with mid-size properties in particular were actively engaged in improving wildlife habitat.

Research testing overstory-understory relationships in hardwood rangelands was sponsored by the IHRMP. Results showed that most notably in drier parts of the state, an oak canopy of 50\% or less does not reduce forage production, and in some cases, can extend the availability of green feed by increasing the species and phenological diversity of the grassland (Frost and McDougald 1989, McClaran and Bartolome 1989). This information was promoted through educational materials and workshops, and while removing oaks for increased forage production was the major reason large landowners gave for removing healthy oaks in 1985 , today it is one of the least important reasons and is seldom done. Program efforts directed at smaller property owners have also apparently paid off. Owners of small properties tend not to cut oaks for economic reasons such as increasing forage production, but instead cut them for home use and landscaping. Since 1985, the frequencies of these practices have declined significantly, especially on small properties. Landowners are also much less likely to sell firewood than they were in 1985 , perhaps reflecting program efforts to increase awareness that oak harvest may not always be sustainable. In fact, a landowner in 1992 is far more likely to agree that "oaks are being lost in California" than they were in 1985.

The effects of these changes in practices are more widespread than it appears from the relative proportion of landowners in Table 5. Clearing oaks for increased forage, to increase waterflow, or to sell firewood typically takes place over greater area per owner than removing a few oaks to put in a road or trail for better access. On the other hand, experts advise that in many cases where oak densities are greater than $50 \%$, or where the oaks are mostly evergreen species such as Quercus agrifolia Nee, Q.chrysolepis Liebm., or Q.wislizeni A.DC. (California, canyon, and interior live oak), thinning of oaks for enhanced forage production, wildlife habitat, and amenity values can be part of a con- 
servation-based resource management program (Standiford 1996).

\section{Grazing is still the major land use}

The data show a statistically significant reduction in the use of hardwood rangelands for grazing. Results consistently suggest less participation of landowners in livestock groups and economies, with fewer landowners in all land ownership size categories reporting ranching as a major income source, or belonging to a livestock-related association or group, although these changes are not statistically significant. In fact, livestock production remains an important activity and major underlying goal for the owners of most of the hardwood rangelands. This is especially true for larger parcels-in both 1985 and 1992, more than half of the owners in the largest property size category reported ranching as their major income source, and more than $85 \%$ produced livestock on their properties. Other studies have also indicated that about three-fourths of California's hardwood rangelands are grazed by livestock (Bolsinger 1988, Holzman 1993, Swiecki and Bernhardt 1993), and that although less than half of ranches are solely supported by ranching (Richards and George 1996), ranching is the most important source of household identity for the majority of ranchers (Richards and George 1996, Bartlett et al. 1989). Conservation of hardwood rangelands on any large scale will require the participation of the livestock industry.

\section{Landowners are not receptive to regulation}

As also indicated by other studies, ranchers and hardwood rangeland landowners are not fond of regulatory options (Ellickson 1991, Huntsinger and Hopkinson 1996). However, the results suggest that they are receptive to education and information programs, as well as to incentive programs like the California Land Conservation Act or "Williamson Act," that reduce the costs of high land values for producers. A dramatic increase in landowner perception of the loss of California's oaks has occurred in the last seven years and landowners have reduced cutting and increased protection of oaks. Stewart (1991) indicates that ranchers are more willing to accept "carefully crafted oak related ordinances" than is revealed in the general response to oak use regulation presented in this study.

Hardwood rangeland landowners are shown here to be active managers of water on their lands, just as they are of oaks, and it seems possible that research, education, and information programs directed toward improvement of water quality could be quite effective.

\section{Conclusions}

Landowner behavior and attitudes can apparently be changed through applied research and extension. Several of the behaviors targeted by the Integrated Hardwood Range Management Program (IHRMP), including cutting of oaks for forage production enhancement and home firewood use, have shown especially dramatic reductions. Selling of firewood is also less common. Landowners more often value oaks for diverse reasons, including for wildlife habitat, and they are aware that oaks are losing ground. This change in values is linked to increased landowner implementation of oak-promoting activities. These changes in values and behavior have occurred among ranchers and other owners of large properties, as well as the owners of small properties whose goals do not include livestock production. Landowners who have been in contact with University of California and other public advisory services about oaks are mure likely to carry out management practices that promote oaks. A multi-agency program like the IHRMP may influence landowners though a variety of advisory contacts, as well as word of mouth from peers.

The results of this study have shown that ranchers and other owners of large properties have changed their management behaviors in ways encouraged by the IHRMP. Because ranching and livestock production, by maintaining large open space areas in private, productive ownerships, can play a critical role in conserving California's natural resources, changes in the attitudes and practices of these landowners are important. By linking reserve areas and parks, the privately owned woodlands can magnify reserve effectiveness in protecting wildlife populations. Landowners, however, tend to be adamant about protecting their own rights to use their land as they see fit, including selling the land at a profit for real estate development (Huntsinger and Hopkinson 1996). Often the land represents the majority of a family's financial assets and they feel threatened by any public tendency to view the state's remaining open space as having an implicitly "public" character, particularly when government regulation is the result. Working through this dilemma will challenge Californians in decades to come.

While a program of research and extension can help reduce land use change by contributing to the economic well-being of ranchers through better or more diverse management, and the enjoyment of hardwood rangelands by small property owners through enhanced wildlife and aesthetic values, it cannot hope to prevent massive land use change as California's population continues to expand into rural areas (Teitz 1990). There continues to be a fairly rapid turnover of properties in the woodlands, and an increase in small parcel sizes. The fragmentation of the woodlands is by all accounts haphazard, the result of development opportunities that do not take into consideration conservation biology principles such as the protection of migration corridors and critical habitat, much less the imperatives of rangeland livestock production. Livestock grazing for fire hazard reduction, as is common in many California urban-rural interface areas, may become infeasible if land use change makes it impossible to sustain the livestock industry. Research and extension efforts must be complemented by efforts to influence the course of land use change in the hardwood rangelands.

\section{Literature Cited}

Bartlett, E.T., R.G. Taylor, J.R. McKean, and J.C. Hof. 1989. Motivation of Colorado ranchers with federal grazing allotments. J. Range Manage. 42:454-456.

Bolsinger, C. 1988. The hardwoods of California's timberlands, woodlands, and savannas. U.S. Forest Serv., Pac. Northwest For. and Range Exp.Sta. Res. Bull. PNW-RB-148. Portland, Ore.

Burcham, L.T. 1982. California range land: an historico-ecological study of the range resource of California. Center for Archeological Res. at Davis Publ. Number 7. Univ. Calif. Davis, Calif.

Dillman, D.A. 1978. Mail and telephone surveys: the total design method. Wiley and Sons, N.Y.

Ellickson, R.C. 1991. Order without law: how neighbors settle disputes. Harvard Univ. Press, Cambridge, Mass. 
Ewing, R.A., N. Tosta, R. Tuazon, L. Huntsinger, R. Marose, $K$. Nielson, R. Motroni, and S. Turan. 1988. Growing conflict over changing uses. Calif. Dept. of For. and Fire Protection. Anchor Press, Sacramento, Calif.

Fortmann, L.P. and L. Huntsinger. 1989. The effects of non-metropolitan population growth on resource management. Society and Natura Resources. 2(1):9-22.

Frost, W.E. and N.K. McDougald. 1989. Tree canopy effects on herbaceous production of annual rangeland during drought. J. Range Manage. 42:281-283.

Griffin, J.R. 1978. Oak woodland. p. 383-416. In: Barbour, M.G. and J. Major (eds.). Terrestrial vegetation of California. John Wiley and Sons, N.Y.

Hargrave, T. 1993. The impact of a federal grazing fee increase on land use in El Dorado County, California. M.S. Thesis. Univ. Calif. Berkeley, Calif.

Holzman, B. 1993. Vegetation change in Californian oak woodlands. Ph.D. Dissertation. Univ. Calif. Berkeley, Calif.

Huntsinger, L. and L.P. Fortmann. 1990. California's privately owned oak woodlands: owners, use, and management. J. of Range Manage. 42(3): $147-52$

Huntsinger, L. and P. Hopkinson. 1996. Sustaining rangeland landscapes. J. Range Manage. 49(2):167-173.

James, J.W. 1966. A modified Koeppen classification of California climates according to recent data. The Calif. Geographer 7:1-12.

Johnson, S. 1996. Factors contributing to land use change in the hardwood rangelands of two central Sierran counties. In: Proc., Symposium on Oak Woodlands at the Urban-Rural Interface, March 18-20, 1996, Cal Poly San Luis Obispo, Calif. Pac. Northwest For. and Range Exp.Sta. Gen. Tech. Rep., Portland, Ore.

Mayer, K.E., P.C. Passof, C. Bolsinger, W.W. J. Grenfell, and H. Slack. 1986. Status of the hardwood resource of California: a report to the Board of Forestry. Calif. Dept. of Forest. and Fire Protection, Sacramento, Calif.

McClaran, M.P. and J.W. Bartolome. 1985. The importance of oaks to ranchers in the California Foothill Woodland. Rangelands 7(4):158-161.
McClaran, M.P. and J.W. Bartolome. 1989. Effect of Quercus douglasii (Fagaceae) on herbaceous understory along a rainfall gradient. Madrono 36:141-153.

McClaran, M.P., J. Romm, and J.W. Bartolome. 1985. Differential farmland assessment and land use planning relationships in Tulare County, California. J. Soil and Water Conserv. 40:252-255.

Muick, P.C. and J.W. Bartolome. 1987. An assessment of natural regeneration of oaks in California. Calif. Dept. of Forest. and Fire Protection, Sacramento, Calif.

Richards, R. and M. George. 1996. Evaluating changes in range management practices through extension education. J. Range Manage. 49(1):76-80.

Spicer, C.C. 1972. Calculation of power sums of deviations about the mean. Appl. Stat. 21:226-227.

Standiford, R. (tech. coord.) 1996. Guidelines for managing California's hardwood rangelands. Division of Agr. and Natural Resource, Publ. 3368. Univ. Calif., Oakland, Calif.

Stewart, W. 1991. Monitoring values and practices of oak woodland decision makers on the urban fringe. pg. 174-182. In: R.B. Standiford, (tech. coord.) Proc., Symposium on Oak Woodlands and Hardwood Rangeland Management, Oct. 31-Nov. 2, 1990, Davis, Calif. Pac. Southwest Forest and Range Exp. Sta. Gen. Tech. Rep. PSW-126. Berkeley, Calif.

Swiecki, T.J. and E.A. Bernhardt. 1993. Factors affecting blue oak sapling recruitment and regeneration. Calif. Dept. of Forest. and Fire Protection, Strategic Planning Program, Sacramento, Calif.

Teitz, M.B. 1990. California growth: hard questions, few answers. pg. 35-74. In: J.J. Kirlin and D.R. Winkler (eds.) California policy choices, vol. 6. School of Pub. Admin., Univ. of So. Calif., Los Angeles, Calif.

USDA, Forest Service. 1981. Resource evaluation field instructions for California, 1981-1984. Pacific Northwest For. and Range Exp. Sta., Portland, Ore.

Wensel, L.C. 1983. Estimators for use in California forestland ownership studies. Univ. Calif. Dep. of Forest. and Resource Manage., Biometrics Note \#8. Berkeley, Calif. 